\title{
Measuring E-Commerce Success in Malaysia: Modified Delone Mclean Model with Trust and Privacy
}

\author{
Najma Imtiaz Ali ${ }^{1,2}$, Suhaila Samsuri ${ }^{1}$, Muhamad Sadry Abu Seman ${ }^{1}$, Imtiaz Ali Brohi $^{1}$, Asadullah Shah ${ }^{1}$ \\ ${ }^{I}$ Department of Computer Science, of Information and Communication Technology, International Islamic University Malaysia \\ ${ }^{2}$ Institute of Mathematics and Computer Science, University of Sindh, Jamshoro, Pakistan \\ *Corresponding author E-mail: suhailasamsuri@iium.edu.my
}

\begin{abstract}
With the influx of the Internet, Business to Customer E-commerce (B2c e-Commerce) has gained popularity around the globe. Although a number of researches has been done to know the factors affecting the adoption of e-commerce, however, not much research has done to know the effects of e-commerce on online shopping success. DeLone and McLean introduced the Information System (IS) success model in year 1992, later on, refined the same model with the newer concept, to fully understand the effects of IS success. In this paper, authors have used the DeLone and McLean IS success model 2003 with addition two constructs Privacy and Trust. Seven interrelated dimensions of e-commerce were examined namely, Service Quality, System Quality, Trust, Privacy, User satisfaction and Net benefits. The proposed model and the relationship between the various constructs were measured by gathering the data from 381 users from the business faculty of Klang valley universities in Malaysia. Seven interconnected dimensions of B2C e-commerce success were confirmed namely, Service Quality, System Quality, Information Quality, Trust, Privacy along with User Satisfaction and Net Benefits. Confirmatory Factor Analysis CFA and SEM were used to analyse the collected data and proved the hypothesis. The results revealed that system quality, service quality, trust and privacy are directly related to user satisfaction which in turn directly related to net benefits, whereas information quality has no any influence on user satisfaction in terms of e-commerce.
\end{abstract}

Keywords: E-commerce, DeLone \& McLean Model, Trust, Privacy, Malaysia

\section{Introduction}

The revolution of the Internet has changed the way of doing business and its development in the field of IT has empowered many retailers to expand their business from limited geographical borders to vast markets and enabled consumer to shop from anywhere anytime [1]. The internet is being utilized for every purpose including education and entertainment. Apart from these activates it has provided a valuable tool for the business to run business related activates and transactions. In addition, it has provided the tool for access and interact with one other through websites owned by the business, which has not only reduced the business running costs but also enabled the business to run smoothly and better [2]. Thus, the Internet provides two forms of marketing convenience to the seller \& buyer. The buyer utilizes the service due to diversity of services such as availability of various products before making buying decision, and delivery of product at doorstep which makes it suitable for many reasons (e.g. avoids travelling, saving time \& resources); while, industries make use of Internet to communicate with consumers and offer a wide range of products. Thus, it has become a vital tool for marketing to increase the potential of trade and commerce. With e-commerce business could operate 24/7 without any disturbance and consumers can access the products, order their products, and payment can be done at the time of product delivery that could be in cash or pay online. Also, the Internet has added the value for customers to compare the products, collect the data, and search for the relevant information, compare that information related with other products or services and make the best choice before using it. In addition, it has enabled the individ- uals to do business through social networking channels, and this has been possible because of the Internet which has offered a platform to sell and purchase of products \& services without having a registered website. However, the large firms run do the business through their websites. Whereas, the drive of offline business is different from the online business. In offline business, customer interacts with the seller; while in online business the best tool for the business is their website through which customer interacts with the seller and browse the products [3]. In order to attract and retain the customers the business is solely dependent on the quality of the website [3], [4]. The quality of the business is associated with technology and the growth in innovative technology demands to understand the factors which are associated with the success of the business, as there is high competition between the service provides. Therefore, various models and theories have been introduced to understand human behaviour towards such changes and their level of acceptance and rejection towards innovative changes within the business. E-commerce success and customer intention has been measured through different theories and models, however, until now the use of Delone and McLean model has been widely used, as it provides a comprehensive understanding of the factors which as associated with information system success [5]. This paper contributes to the literature by identifying factors that affect the success of e-commerce among Malaysian consumers and the contribution of this paper will have significance on theoretical and practical grounds identifying the e-commerce success factors. 


\section{Theoretical Background}

The large investments by companies for implementing the IS with the anticipation of high productivity benefits, sustaining in competitive business settings, and cutting administrative and operational costs [1]. Although, the existence of e-commerce can be found back in year 1965 when consumers were able to withdraw cash from by using Automated Teller Machines (ATM) and use of POS terminals for purchasing [2], [3]. Management of ecommerce involves two side activities i.e. buy and sell by prioritizing the resources in order to deliver the desired benefits [4]. Despite of the fact that a large number empirical studies have been conducted in IS success. The researchers have neither agreed nor found what does exactly "IS success" defines [5]. IS success has appeared one of the controversial issues among IS researchers due to multidimensional concept of success which can be assessed at various levels. The DeLone and McLean work was appreciated among IS researchers and considered as breakthrough in measuring IS success [3]. DeLone \& McLean introduced first IS success model back in 1992 by introducing six major factors i.e. "System Quality", "Information Quality", "Use", "User Satisfaction", "Individual Impact", and "Organizational Impact". They defined that these categories are interrelated and comprehensively define the IS success [6]. However, D\&M model had many confusions in terms of IS success measurers [7]. In order to address such confusions reported by many researchers such as [3], [7]; D\&M introduced a comprehensive IS success model in year 2003 by adding some new factors "Service Quality" and replacing "Individual Impact" \& "Organizational Impact" with "Net Benefits". This model has now been tested in various contexts in order to measure the IS success factors.

\section{Proposed Research Model}

IS Success have been examined and assessed through various aspects and sometimes tested in different contexts. People, technology, and process are the prime aspects of that have main influence an IS success. Models such as DeLone and McLean Information System success model (D\&M IS), the Seddon respecification of the D\&M IS success model, and DeLone and McLean IS successes updated model. These models have focused on IS success factors and this study have used the following factors to measure and assess the success of e-commerce among Malaysian consumers. Figure 1 demonstrates the proposed model with hypothesis.

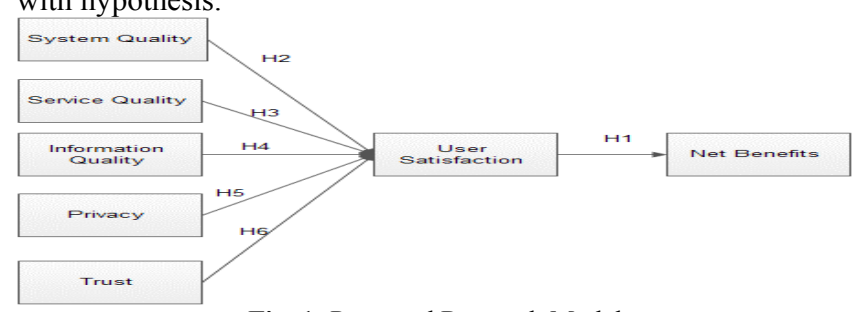

Fig. 1: Proposed Research Model

\subsection{Constructs \& Hypothesis}

\subsubsection{Net Benefits}

When a consumer of any product or service uses that products, it evaluates and assess the positive and negative aspects and such that user satisfaction is directly related with the benefits a consumer receives and it is main driving force behind the user satisfaction [8]. The usage of IS differs between consumer who desire to purchase a product or intends to avail a service while an employee with organization make us of IS for work purpose. Net benefits address the success of e-commerce while a consumer make use of the service or products and it indicates the important factor of success measurement [9]. The impact of website design and the information available are interrelated which define "system quality" and "information quality" which eventually guide to measure the consumer purchases [10].

\subsubsection{User Satisfaction}

User satisfaction is an important factor in order to measure the success of IS system including e-commerce. It deals with customers emotion and belief towards usage of the particular system by getting what he/she desired to while using the system. During and after using e-commerce business a consumer looks at aspects offered by the provider such as informational, service, support, and transactional process until reception of the service or product offered by the online vendor [6]. At the point when a shopper/consumer is satisfied with either the service or product, it defines the satisfaction. it can likewise be an individual's sentiments of joy or disappointment that outcomes from contrasting an item's apparent execution or result with their desires. In addition, there are chances of continuous effect on consumer satisfaction until the process is completed [11] [12] [13]. Thus, the e-commerce divides it into three stages of the process i.e. information/data search, purchase stage, and post purchase stage [8]. Tse and Wilton (1988), defined customer satisfaction as "the consumer's response to the evaluation of the perceived discrepancy between prior expectations and the actual performance of the product or service as perceived after its consumption" [14]. Thus, user satisfaction is an important factor in any environment when it comes to e-commerce it becomes highly important to satisfy the needs of consumers in order to the success of a business.

H1: "User satisfaction has a positive effect on the net benefits".

\subsubsection{System Quality}

Quality of any product or service is measured through what is offered and capable to satisfy the required needs of the consumer [8]. System quality as "the desirable characteristics of an information system. For example: ease of use, system flexibility, system reliability, and ease of learning, as well as system features of intuitiveness, sophistication, flexibility, and response times" [11]. The concept of system quality was introduced by DeLone \& McLean in e-commerce. Whereas, Seddon elaborated that it relates to the use of the system, easiness of the system, and absence and presence of errors during the process [6]. Also, Wang found that "system quality", "ease of use", "system quality" and "user satisfaction" have a positive relationship between these factors [12]. Therefore, the quality of system offered in online environment has importance as it is associated with customer needs and satisfaction.

H2: "System quality has a positive effect on user satisfaction in ecommerce to achieve the net benefits".

\subsubsection{Service Quality}

Service quality refers to the service offered by business to their clients during e-commerce business every customer expects high standards of service and if not provided the business will lose their customers in the competitive online business environment. [8] defined service as "any intangible act or performance that one party offers to another that does not result in the ownership of anything". Service quality in marketing refers to the consumer's outlook of services that meet or exceed their expectations. While in e-commerce environment consumers decision made by assessing the quality and excellence of e-services is based on the services given by the e-vendor.

H3: "Service quality has a positive effect on the user satisfaction in e-commerce to achieve the net benefits".

\subsubsection{Information Quality}

Petter et al., (2008) defined information quality as "the desirable characteristics of the system outputs; that is, management reports, 
and Web pages" [15]. The use of information quality mainly focuses on generating reports for e-vendors as well provides documentational support to the customers. The traditional measurement of IS success has been done through information quality [13]. In the context of e-commerce, information is being delivered by webserver to the consumers. Thus, it indicates that the role of the website within e-commerce is to provide information regarding products and services [14]. The information provided on the website represents the products and services and assists online shoppers to buy products based on the information available.

H4: "Information quality has a positive effect on the user satisfaction in e-commerce to achieve the net benefits".

\subsubsection{Privacy}

According to [14] privacy refers to "a moral right of individuals to avoid intrusion into their personal affairs by third parties". Privacy has high importance in the online environment as such potential privacy violation is frequently reported [15]. Privacy is one of key issues in online, it has been discussed for a while that who will have the customer data and in long-term run it will prove to be a source of customer retention [15]. Privacy of personal data such as our identities like and dislikes is a major concern to consumers, particularly with the dramatic increase in identity theft. Thus, it is one of the major concerns for the individuals while using ecommerce services where they have thought about the privacy of personal data and identity might be at risk and compromised [14]. H5: "Privacy has a positive effect on user satisfaction in ecommerce to achieve the net benefits".

\subsubsection{Trust}

Online trust is regarded as reliance on a specific firm service or products by its consumers and stakeholders with regards to the business activities offered through electronic medium or website [16]. Consumer trust is one of the frequent constructs which has been studied in various fields including e-commerce literature [17]. The online vendor's key target is to retain customers trust [18]. The key mechanism that governs the relationships between parties by uncertainty, dependency and vulnerability are based on trust [19]. Whereas, within the e commerce platform where buyer and seller could not meet and see each other have a relationship based on the trust.

H6: "Trust has a positive effect on the user satisfaction in ecommerce to achieve the net benefits".

\section{Research Methodology}

This research adopted cross-sectional quantitative method in order to measure the factors of e-commerce success. The design of the questionnaire was based on items adopted and adapted from previous studies and modified according to the needs of this research objectives. The sampling method used for this study was Simple Random Sampling (SRS) method. In this method of sampling everyone has an equal chance and fair probability of being selected as sample of the population [16]. The sample for this study was collected from undergraduate and postgraduate students of business faculty of various universities in Klang Valley in Malaysia between August to October 2018. The business students have more awareness towards the e-commerce adoption and more experienced in terms of e-commerce [17].

\subsection{Instrument Design}

DeLone \& McLean (2004) advice the researchers who wish to calculate the IS Success "Researchers and practitioners should not let themselves be carried away by the hype of the new economy and led to believe that this new and rapidly changing environment requires entirely new measures of IS success. One should look first at the cumulative tradition and determine which existing and validated success measures can be used in the e-commerce environment. As much as possible, tried and true measures should be enhanced and expanded with modifications or, where necessary, new measures should be considered. Selection of e-commerce success dimensions and measures should be contingent on the objectives and the context of the empirical investigation, but tested and proven measures should be used whenever possible. Completely new and untested metrics should be adopted only as a last resort" (p. 43) [9].

By keeping the above statement, we just continue our research with the existing IS success model with the extension of two important factors that are privacy and trust. Table 1 shows the source of adoptive items for this study.

The questionnaire was divided into two sections. Section A contains the Demographic profiles of respondents such as Age, Gender, income, internet usage experience, and e-commerce usage experience. and the internet usage information, whereas section $\mathrm{B}$ contains the items measured on 5-point Likert scale, affixed by Strongly Disagree (1) to Strongly Agree (5).

Table 1: Instrument Items

\begin{tabular}{|c|c|c|}
\hline Measure & Number of Items & Source \\
\hline System Quality & 7 & {$[18]$} \\
\hline Service quality & 4 & {$[19]$} \\
\hline Information Quality & 7 & {$[20]$} \\
\hline Trust & 7 & {$[21]$} \\
\hline Privacy & 5 & {$[22]$} \\
\hline $\begin{array}{c}\text { User (customer e-Commerce) } \\
\text { satisfaction (US) }\end{array}$ & 5 & {$[22]$} \\
\hline Net benefits & & {$[23]$} \\
\hline
\end{tabular}

\section{Data Analysis}

This section presents the results of data analysis.

\subsection{Demographic Results}

The demographic profile for the respondents is given in Table 2 . There were $49 \%$ Male and $51 \%$ female respondents. For Age group, there were $42.25 \%$ respondents in the age group of 26-30, followed by respondents $(26.50 \%)$ in the age group below 25 . For age group $31-40$ and above 40 we have $25.72 \%$ and $5.5 \%$ respondents respectively. For education the highest respondents belong to group diploma with $26.77 \%$. Income mostly respondents belong to 4,000 to 5,999 groups with $29.39 \%$.

Table 2: Demographic Results

\begin{tabular}{|c|c|c|c|}
\hline $\begin{array}{c}\text { Demographic Infor- } \\
\text { mation }\end{array}$ & $\begin{array}{c}\text { Variables } \\
\text { Names }\end{array}$ & Frequencies & Percentage \\
\hline \multirow{2}{*}{ Gender } & Males & 187 & $49 \%$ \\
\hline \multirow{3}{*}{ Age } & Females & 194 & $51 \%$ \\
\cline { 2 - 4 } & Below 25 & 101 & $26.50 \%$ \\
\cline { 2 - 4 } & $26-30$ & 161 & $42.25 \%$ \\
\cline { 2 - 4 } & $31-40$ & 98 & $25.72 \%$ \\
\hline \multirow{3}{*}{$\begin{array}{c}\text { Highest education de- } \\
\text { gree }\end{array}$} & Above 40 & 21 & $5.5 \%$ \\
\cline { 2 - 4 } & High school & 87 & $22.83 \%$ \\
\cline { 2 - 4 } & Diploma & 102 & $26.77 \%$ \\
\cline { 2 - 4 } & Bachelor & 104 & $27.29 \%$ \\
\hline \multirow{3}{*}{\begin{tabular}{c} 
Income(RM) \\
\cline { 2 - 4 }
\end{tabular}} & Masters & 88 & $23 \%$ \\
\cline { 2 - 4 } & $0-1,999$ & 90 & $23.62 \%$ \\
\cline { 2 - 4 } & $2000-3,999$ & 98 & $25.72 \%$ \\
\hline & $4000-5,999$ & 112 & $29.39 \%$ \\
\hline
\end{tabular}

Table 3 shows the respondents Internet and e-commerce experience. $74.80 \%$ respondents have Internet at their home. Mostly $(52 \%)$ respondents were using the Internet for more than 7 years and others 4-6 (17.84), 6-7(16.2\%), 1-4 (10.76\%) and below 1 $(3.14 \%)$. Mostly $(69.55 \%)$ respondents using e-commerce for $1-4$ 
years followed by 4-6 (12.33\%), 6-7 (9.98\%) below 1 (6.5\%) and Above $7(1.57 \%)$. Most of the respondent do e-commerce once in a month $(38.05 \%)$ followed by few times in a month $(25.72 \%)$, quarterly (16.27\%) weekly (11.28\%) and yearly $(8.66 \%)$.

Table 3: Internet and E-commerce Experience

\begin{tabular}{|c|c|c|c|}
\hline $\begin{array}{l}\text { Demographic } \\
\text { Information }\end{array}$ & $\begin{array}{c}\text { Variables } \\
\text { Names }\end{array}$ & Frequency & Percentage \\
\hline \multirow{2}{*}{$\begin{array}{c}\text { Do you have Internet access } \\
\text { at home? }\end{array}$} & yes & 285 & $74.80 \%$ \\
\hline & No & 96 & $25.2 \%$ \\
\hline \multirow{5}{*}{$\begin{array}{l}\text { How long you are using } \\
\text { Internet(Years) }\end{array}$} & Below 1 & 12 & $3.14 \%$ \\
\hline & $1-4$ & 41 & $10.76 \%$ \\
\hline & $4-6$ & 68 & $17.84 \%$ \\
\hline & $6-7$ & 62 & $16.27 \%$ \\
\hline & Above 7 & 198 & $52 \%$ \\
\hline \multirow{5}{*}{$\begin{array}{l}\text { How long you are using E- } \\
\text { commerce(Years) }\end{array}$} & Below 1 & 25 & $6.5 \%$ \\
\hline & $1-4$ & 265 & $69.55 \%$ \\
\hline & $4-6$ & 47 & $12.33 \%$ \\
\hline & $6-7$ & 38 & $9.98 \%$ \\
\hline & Above 7 & 6 & $1.57 \%$ \\
\hline \multirow{5}{*}{$\begin{array}{c}\text { Frequency of E-commerce } \\
\text { usage }\end{array}$} & $\begin{array}{c}\text { Few times in } \\
\text { moth }\end{array}$ & 98 & $25.72 \%$ \\
\hline & $\begin{array}{l}\text { Once in a } \\
\text { month }\end{array}$ & 145 & $38.05 \%$ \\
\hline & weekly & 43 & $11.28 \%$ \\
\hline & quarterly & 62 & $16.27 \%$ \\
\hline & Yearly & 33 & $8.66 \%$ \\
\hline
\end{tabular}

\subsection{Item Analysis and Reliability Estimates}

\subsubsection{Statistical Analysis}

The study highlighted seven constructs, that are Service Quality (SQ). System Quality (SQ), Information Quality (IS), Privacy (P), Trust (T) and User Satisfaction (US) and Net benefits (NB) which serve as the background of the research. Confirmatory Factor Analysis (CFA), reliability and validity analysis were used to measure the validity and interconsistency of the items. In addition, descriptive data analysis was performed with SPSS 23.0 and this study utilized an advanced statistical method that is Structural Equation Modelling (SEM) by using AMOS version 23.0.

\subsubsection{Confirmatory Factor Analysis (CFA)}

The main aim of the Confirmatory Factor Analysis (CFA) in the present research is to measure the unidimensionality of the dimensions employed in the study. It is important for evaluating and measure the model by using a variety of Goodness-of-Fit (GOF) indices [24]. The model fit assessment for this study was based on various estimations, chi-square $\chi^{2}$ or $\chi^{2}$ /df ratio, Comparative Fit Index (CFI), the Root Mean Square Error of Approximation (RMSEA). The estimations along with their values are shown in Table 4.

Table 4: Summary of Fit Indices

\begin{tabular}{|c|c|c|c|c|}
\hline $\begin{array}{l}\text { Measure } \\
\text { Indices }\end{array}$ & $\begin{array}{c}\text { Fit } \\
\text { Indices }\end{array}$ & Results & Criteria & Reference \\
\hline \multirow{4}{*}{$\begin{array}{c}\text { Absolute fit } \\
\text { measure }\end{array}$} & $\mathrm{X} 2$ & 1342 & & \\
\hline & Df & 765 & & \\
\hline & $\mathrm{X} 2 / \mathrm{Df}$ & 1.987 & $\begin{array}{c}1<\chi 2 / \mathrm{df} \\
<3\end{array}$ & [25] \\
\hline & RMSEA & .079 & $<=0.08$ & [26] \\
\hline \multirow{3}{*}{$\begin{array}{l}\text { Incremental fit } \\
\text { measure }\end{array}$} & NFI & .901 & $\geq 0.90$ & [27] \\
\hline & TLI & .911 & $\geq 0.90$ & [25] \\
\hline & CFI & .900 & $\geq 0.90$ & {$[28]$} \\
\hline $\begin{array}{l}\text { Parsimony fit } \\
\text { measure }\end{array}$ & AGFI & .890 & $\geq 0.80$ & [25] \\
\hline
\end{tabular}

Notes: $\chi 2$ = chi-square; $\mathrm{df}=$ degree of freedom; RMSEA = root mean square error of approximation; NFI = normated fit index; CFI = comparative fit index; TLI = Tucker-Lewis index, AGFI = adjusted GOF index.

CFA was estimated on the seven constructs presented by the study in order to ascertain the reliability and validity of these constructs in the research context. These six items are then collapsed into one item, External and Internal Factor indicator. This study used the convergent validity in order to postulate the capability of the measurement items, measure the construct of the study impeccably [29]. [30], also added that the SEM is the appropriate tools to be used to calculate the convergent validity of the construct. Convergent validity positively relate the constructs alternative measures [31] . Convergent validity can be measured by the critical ratio (C.R), any parameter that has the value of C.R $>1$ and probability $\mathrm{p}>0.5$, then it is considered a significant [32].

In this study C.R value for all construct found as $>1$ at $p>0.5$, therefore the criteria for the convergent validity is fulfilled. Beside the convergent validity, the composite reliability should be $>0.7$ as well as the variance extracted AVE values should be greater than 0.5 in order to the significantly reliable construct[33][34]. In order to measure the composite reliability and the variance extracted Farnell and Larker's formula was used as shown below [26].

$$
\operatorname{RR}=\frac{\left(\sum_{i=1}^{n} x_{i}\right)^{2}}{\left(\sum_{i=1}^{n} x_{i}\right)^{2}+\left(\sum_{i=1}^{n} s_{i}\right)}
$$

Formula 1: Composite Reliability Fornell and Larcker's (1981)

$$
=\frac{\sum_{i=1}^{n} \lambda_{i}^{2}}{n}
$$

Formula 2: Variance Extract Fornell and Larcker's (1981)

\subsubsection{Reliability and Validity of the External and Internal Factors Indicator}

Table 5: Composite Reliability and Variance Extracted of External and

\begin{tabular}{|c|c|c|c|c|c|}
\hline $\begin{array}{c}\text { Variable } \\
\text { Name/Items }\end{array}$ & Label & Loading & \begin{tabular}{|c} 
Composite Relia- \\
bility
\end{tabular} & AVE & $\begin{array}{c}\text { Cronbach's } \\
\text { Alpha }\end{array}$ \\
\hline System quality & SQ & & 0.872 & 0.495 & 0.876 \\
\hline SQ 1 & & .58 & & & \\
\hline SQ 2 & & .73 & & & \\
\hline SQ 3 & & .71 & & & \\
\hline SQ 4 & & .72 & & & \\
\hline SQ 5 & & .77 & & & \\
\hline SQ6 & & .68 & & & \\
\hline SQ7 & & .72 & & & \\
\hline System quality & $\mathrm{S}$ & & 0.811 & 0.521 & 0.887 \\
\hline S1 & & .58 & & & \\
\hline S2 & & .78 & & & \\
\hline S3 & & .73 & & & \\
\hline S4 & & .78 & & & \\
\hline $\begin{array}{c}\text { Information } \\
\text { quality }\end{array}$ & IS & & 0.857 & 0.462 & 0.873 \\
\hline IS1 & & .76 & & & \\
\hline IS 2 & & .66 & & & \\
\hline IS 3 & & .67 & & & \\
\hline IS 4 & & .63 & & & \\
\hline IS5 & & .70 & & & \\
\hline IS6 & & .62 & & & \\
\hline IS7 & & .71 & & & \\
\hline Trust & $\mathrm{T}$ & & 0.888 & 0.533 & 0.889 \\
\hline $\mathrm{T} 1$ & & .72 & & & \\
\hline T 2 & & .73 & & & \\
\hline T 3 & & .69 & & & \\
\hline T 4 & & .76 & & & \\
\hline T 5 & & .78 & & & \\
\hline Т 6 & & .74 & & & \\
\hline
\end{tabular}
Internal Factor 


\begin{tabular}{|c|c|c|c|c|c|}
\hline T 7 & & 6 & & & \\
\hline Privacy & $P$ & & 0.849 & 0.534 & 0.873 \\
\hline P1 & & .59 & & & \\
\hline P 2 & & .67 & & & \\
\hline P 3 & & .84 & & & \\
\hline $\mathrm{P} 4$ & & .79 & & & \\
\hline P5 & & .74 & & & \\
\hline User Satisfaction & US & & 0.901 & $\mid 0.648$ & 0.932 \\
\hline US1 & & .79 & & & \\
\hline US2 & & .75 & & & \\
\hline US3 & & .78 & & & \\
\hline US4 & & .83 & & & \\
\hline US5 & & .87 & & & \\
\hline Net Benefits & & & 0.867 & $\mid 0.428$ & 0.897 \\
\hline NB1 & & .76 & & & \\
\hline NB2 & & .78 & & & \\
\hline NB3 & & .89 & & & \\
\hline NB4 & & .65 & & & \\
\hline NB5 & & .67 & & & \\
\hline
\end{tabular}

\section{Results}

The outcomes of the analysis were assessed in order to determine the relationships between all variables and the strength of each variable in predicting IS success having achieved the acceptable estimate of best fit. Equally, the SEM analyses were used in seeking the answers to the research questions and afterwards test the hypotheses of the present research. The outcomes of the estimation were arranged in the following sequence to match the order of the respective hypotheses, and the proposed model which illustrates the hypothesized E-commerce model and the relationships between the hypotheses as illustrated in Table 5. However, Table 6 illustrates the summary of the hypothesis results. The responses of research hypothesis are as follow:

H1: User satisfaction has a positive effect on net benefits. (parameter estimates $\beta=.543$, C.R. $=22.706, p=.000$ ).

$H 2$ : System quality has a positive effect on the user satisfaction in e-commerce to achieve the net benefits (parameter estimates $\beta=$ .342$, C.R. $=13.575, \mathrm{p}=.000)$.

H3: Service quality has a positive effect on the user satisfaction in e-commerce to achieve the net benefits $\beta=.490$, C.R. $=13.195, p$ $=.000)$.

H4: Information quality has a positive effect on the user satisfaction in e-commerce to achieve the net benefits (parameter estimates $\beta=.068$, C.R., $p=1.761=.049$ ).

H5: Privacy has a positive effect on the user satisfaction in ecommerce to achieve the net benefits (parameter estimates $\beta=$ .087, C.R. $=8.769, \mathrm{p}=.000$ ).

H6: Trust has a positive effect on the user satisfaction in ecommerce to achieve the net benefits (parameter estimates $\beta=$ .048, C.R. $=22.706, \mathrm{p}=.000$ ).

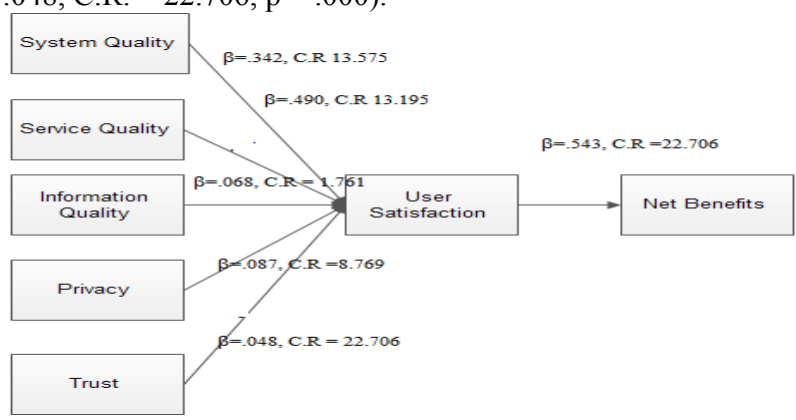

Fig. 2: Final Model
Table 6: Overall Regression Weights: (Group Number 1 - Default Model)

\begin{tabular}{|c|c|c|c|c|c|c|c|}
\hline & & & estimates & SE & C.R. & P & Label \\
\hline US & $<---$ & SQ & .543 & .040 & 13.575 & $* * *$ & \\
\hline US & $<---$ & S & .541 & .041 & 13.195 & $* * *$ & \\
\hline US & $<---$ & IQ & .037 & .021 & 1.761 & .049 & \\
\hline US & $<---$ & P & .456 & .052 & 8.769 & $* * *$ & \\
\hline US & $<---$ & T & .431 & .029 & 14.862 & $* * *$ & \\
\hline NB & $<---$ & US & .890 & .052 & 22.706 & $* * *$ & \\
\hline
\end{tabular}

Table 7: Summary of the Hypothesis Results

\begin{tabular}{|l|l|l|}
\hline No. & \multicolumn{1}{|c|}{ Hypothesis Test } & \multicolumn{1}{|c|}{ Result } \\
\hline H1 & $\begin{array}{l}\text { User satisfaction has a positive effect on the net } \\
\text { benefits. }\end{array}$ & Supported \\
\hline H2 & $\begin{array}{l}\text { System quality has a positive effect on the user } \\
\text { satisfaction in e-commerce to achieve the net bene- } \\
\text { fits. }\end{array}$ & Supported \\
\hline H3 & $\begin{array}{l}\text { Service quality has a positive effect on the user } \\
\text { satisfaction in e-commerce to achieve the net bene- } \\
\text { fits. }\end{array}$ & $\begin{array}{l}\text { Not sup- } \\
\text { ported }\end{array}$ \\
\hline H4 & $\begin{array}{l}\text { Information quality has a positive effect on the user } \\
\text { satisfaction in e-commerce to achieve the net bene- } \\
\text { fits }\end{array}$ & Supported \\
\hline H5 & $\begin{array}{l}\text { Privacy has a positive effect on the user satisfaction } \\
\text { in e-commerce to achieve the net benefits. }\end{array}$ & Supported \\
\hline H6 & $\begin{array}{l}\text { Trust has a positive effect on the user satisfaction in } \\
\text { e-commerce to achieve the net benefits. }\end{array}$ & Supported \\
\hline
\end{tabular}

\section{Discussion}

The major finding which can be construed from the overall result of the present study is that service quality, system quality, trust, privacy factors affect e-commerce success statistically and proved to be significant. However, information quality is not significant according to this study. In view of this, the present study proposed that privacy and trust are also a very important factor in order to draw the success of e-commerce. Based on these outputs the ecommerce businesses should take parameters to ensure the privacy and trust of the user in order to gain the user satisfaction which in turn leads to net benefits.

\section{Conclusion}

Based on the outcome of the study the proposed model of the study fit the data well. Meaning that it is workable and can be practically applied in the e-commerce business. This final model is the adaption of D\&M IS success model along with trust and privacy as the additional constructs. The proposed model has been tested and confirmed in the present to be fit through SEM analysis. Due to the model has been confirmed from the analysis to fit the data well; therefore, it can be seen as the major theoretical contribution of the research to the discipline of e-commerce acceptance factors.

\section{Acknowledgment:}

The paper was funded by grant from International Islamic University Malaysia (RIGS 15-074-0074).

\section{References}

[1] D. Schuette, "Turning E-business barriers into strengths," Inf. Syst. Manag., vol. 17, no. 4, pp. 16-21, 2000.

[2] J. A. Senn, "Business-To-Business E-Commerce," Inf. Syst. Manag., vol. 17, no. 2, pp. 19-28, Mar. 2000.

[3] A. Molla and P. Licker, "E-Commerce Systems Success: An Attempt to Extend and Respecify the Delone and MaClean Model of IS Success.," J. Electron. Commer. Res., vol. 2, no. 4, pp. 131-141, 2001. 
[4] D. Chaffey, Digital_Business_and_E-Commerce_Management. 2015.

[5] E. Garrity and G. Sanders, Information systems success measurement. 1998.

[6] W. H. DeLone and E. R. McLean, "Information Systems Success: The Quest for the Dependent Variable," Inf. Syst. Res., vol. 3, no. 1, pp. 60-95, Mar. 1992.

[7] P. Seddon, "A respecification and extension of the DeLone and McLean model of IS. Information Systems Research," Inf. Syst. Res., vol. 8, no. 3, pp. 240-253, 1997.

[8] W. H. DeLone and E. R. McLean, "The DeLone and McLean model of information systems success: A ten-year update," in Journal of Management Information Systems, 2003, vol. 19, no. 4, pp. 9-30.

[9] W. H. DeLone and E. R. McLean, "Measuring e-Commerce Success: Applying the DeLone \&amp; McLean Information Systems Success Model,” Int. J. Electron. Commer., vol. 9, no. 1, pp. 31-47, Oct. 2004.

[10] W. H. DeLone and E. R. McLean, "Measuring e-Commerce Success: Applying the DeLone \&amp; McLean Information Systems Success Model," Int. J. Electron. Commer., vol. 9, no. 1, pp. 31-47, 2004.

[11] X. Liu, M. He, F. Gao, and P. Xie, “An empirical study of online shopping customer satisfaction in China: a holistic perspective," Int J. Retail Distrib. Manag., vol. 36, no. 11, pp. 919-940, Oct. 2008.

[12] P. Kotler and K. L. Keller, "Marketing management (13th ed.)," in Prentice Hall., 2009.

[13] J. Agbor, "The Relationship between Customer Satisfaction and Service Quality: a study of three Service sectors in Umeå," 2011.

[14] D. K. Tse and P. C. Wilton, "Models of Consumer Satisfaction Formation: An Extension," J. Mark. Res., vol. 25, no. 2, p. 204 May 1988.

[15] S. Petter, W. DeLone, and E. McLean, "Measuring information systems success: Models, dimensions, measures, and interrelationships,” Eur. J. Inf. Syst., vol. 17, no. 3, pp. 236-263, 2008.

[16] N. K. Malhotra, Marketing Research: An Applied Orientation. 2010

[17] D. Gefen, E. Karahanna, and D. W. Straub, "Trust and TAM in online shopping: An integrated model," 2003.

[18] P. B. Seddon, "A Respecification and Extension of the DeLone and McLean Model of IS Success," Inf. Syst. Res., vol. 8, no. 3, pp. 240-253, Sep. 1997.

[19] Y. Wang and J. E. Tang, “AN INSTRUMENT FOR MEASURING CUSTOMER SATISFACTION TOWARD WEB SITES THAT MARKET DIGITAL PRODUCTS AND SERVICES," vol. 2, no. 3, pp. 89-102, 2001.

[20] [20]A. Rai, S. S. Lang, and R. B. Welker, "Assessing the validity of IS success models : An empirical test and theoretic ...," 2002.

[21] [21]B. Suh and I. Han, "E ffect of trust on customer acceptance of Internet banking," vol. 1, pp. 247-263, 2002

[22] M. I. Eid, "Determinants of e-commerce customer satisfaction, trust, and loyalty in Saudi Arabia," J. Electron. Commer. Res., vol. 12, no. 1, pp. 78-93, 2011

[23] Y. S. Wang, H. Y. Wang, and D. Y. Shee, "Measuring e-learning systems success in an organizational context: Scale development and validation," Comput. Human Behav., vol. 23, no. 4, pp. 1792 $1808,2007$.

[24] B. M. (2001) Byrne, Structural Equation Modeling with AMOS Basic Concepts, Applications, and Programming, Mahwah: 2001.

[25] J. F. Hair, W. C. Black, B. J. Babin, and R. E. Anderson, "Multivariate Data Analysis," Vectors. p. 816, 2010.

[26] C. Fornell and D. Larcker, "Evaluating Structural Equation Models with Unobservable Variables and Measurement Error," J. Mark. Res., vol. 18 , no. 1, pp. 39-50, 1981.

[27] A. Aron, E. J. Coups, and E. N. Aron, Statistics for Psychology. 2006.

[28] R. Bagozzi and Y. Yi, "On the Evaluation of Structure Equation Models," no. January, 1988

[29] J. F. Hair, W. C. Black, B. J. Babin, and R. E. Anderson, "MULTIVARIATE DATA ANALYSIS A Global Perspective," 1998

[30] J. . Anderson and D. . Gerbing, "Structural Equation Modelling In Practice: A Review And Recommended Two-Step proach," .Psychological Bull. 103, 411-423, vol. 103, no. 3, pp. 411-423, 1988.

[31] J. F. J. Hair, G. T. M. Hult, C. M. Ringle, and M. Sarstedt, A primer on partial least squares structural equation modeling (PLS-SEM), Second. Sage Publications Inc., 2017.

[32] J. C. J. Anderson and D. D. W. Gerbing, "Structural equation modeling in practice: A review and recommended two-step approach," Psychol. Bull., vol. 103, no. 3, pp. 411-423, 1988.
[33] P. Holmes-Smith, Applied structural equation modeling. Feburay, Canbera., 2002.

[34] B. Hair, J.F., Jr., Multivariate Data Analysis, 6th ed., Upper Saddle River: Pearson Education, Inc. Hardin,. 2006.

\section{Questionnaire}

Items

SQ1. This online retail site is user friendly.

SQ2. Compared to other sites, this online retail site is easy to become familiarized with.

SQ3. I find it easy to get this online retail site to do what I want it to do.

SQ4. I find it easy to become skilful at using this online retail site.

SQ5. I believe that this online retail site is cumbersome to use.

SQ6. To use this online retail site requires a lot of mental effort.

SQ7. I get frustrated when I use this online retail site.

S1. I am satisfied with the customer support provided by this online retail site.

S2. I am satisfied with the after-sales service provided by this online retail site.

S3. This online retail site understands my problems and requests.

S4. This online retail site responds to my requests fast enough.

IS1. This online retail site provides the precise information I need.

IS2. This online retail site provides responses to questions and queries that are exactly what I need.

IS3. This online retail site provides sufficient information to enable me to do my tasks.

IS4. This online retail site has errors that I must work around

IS5. I am satisfied with the accuracy of information provided by this online retail site.

IS6. The output options (printer-friendly options, page sizes allowed for etc.) are sufficient for my use.

IS7 .The information provided by this online retail site is helpful regarding my questions or problems.

T1. This online retail site is trustworthy.

T2. I trust in the benefits of the decisions made by this online retail site, i.e.:

T3. I trust the specials offered and recommendations made by the site.

T4. This online retail site keeps its promises and commitments.

T5. This online retail site keeps customers' best interests in mind

T6. This online retail site would do the job right even if not monitored.

T7 I trust this online retail site.

US1. I am satisfied with making purchases online from this online retail site.

US2. The performance of Web site meets my expectation.

US3.The Web site does not have sufficient experience in the marketing of the products and service that it offers

US4.The Web site knows its users well enough to offer them products and services adapted to their needs

US5.The Web site does not have the necessary resources to carry out its activities successfully.

P1. The Web site abides by personal data protection laws

P2. The Web site only collects user's personal data that are necessary for its activity.

P3. The Web site does not provide my personal information to others without your consent

P4. I feel a safe when sending my personal information to the Web site

P5. The Web site shows concern for privacy of its users.

NB1.The e-commerce system helps the organization provide new products or services to customers.

NB2. The e-commerce system helps the organization save cost.

NB3.The e-commerce system helps the organization to speed up transactions or shorten product cycles.

NB4. The e-commerce system helps the organization increase return on investment.

NB5. The e-commerce system helps the organization to achieve its goal. 